\title{
Cultural Hegemony in Open Distance Learning: Does it Really Matter?
}

\author{
Victor J. Pitsoe \& Mpho M. Dichaba \\ Dept. of Leadership and Management, College of Education \\ University of South Africa \\ Email address: Pitsovj@unisa.ac.za
}

\section{Doi:10.5901/mjss.2013.v4n6p83}

\begin{abstract}
:
Culture is perhaps the most pivotal to all the things that we do in education. However, in the midst of the discourses about improving open distance learning $(O D L)$ in terms of quality, teaching and learning, this paper will argue that little, if any, has been done to make cultural hegemony a central area of investigation. This article will further argue that current practices of the Institute for Open Distance Learning (IODL) at the University of South Africa (Unisa) seem to draw on one set of values (the dominant values). Given that Unisa's ODL is reasonably spread across culturally diverse student population, it usually results in what Antonio Gramsci (1971) calls cultural hegemony. Drawing from Antonio Gramsci's work and culturally relevant pedagogy, this article proposes the reengineering of Unisa's ODL teaching and learning practice.
\end{abstract}

Keywords: Cultural hegemony, open distance learning, culturally relevant pedagogy, generational divide, culture.

\section{Introduction}

Traces of cultural hegemony are noticeable throughout many different societies - they have been omnipresent throughout history. Cultural hegemony is the notion that a diverse culture can be ruled or dominated by one group or class, that everyday practices and shared beliefs provide the foundation for complex systems of domination. While the analysis of cultural domination was first advanced in terms of economic classes, this article holds that it can as well be applied broadly, more specifically in higher education. In this article, we argue that the ideology of cultural hegemony is alive and well within the Institute for Open Distance learning (IODL) as a culturally diverse setting. ODL environments are sites of struggle for practitioners and students - there is a collision of different cultures. Quite often, it is difficult for the ODL practitioners to accommodate each and every student's culture. Therefore, students are expected "to step out of their own culture and temporarily enter into the culture of the ODL practitioners. Contained by this process, problems arise if the ODL practitioners' pedagogical values are not compatible with students' assumptions about how teaching should be done.

Even though there has been much discussion in recent years about the important and extensive role of cultural factors in higher education, the contemporary ODL theory and practice has one fundamental blind spot: it promotes cultural hegemony. Accordingly, cultural institutions, such as churches, schools and universities, create a compatible version of reality, which favours the elite interests. For example, cultural hegemony is characterised within the public educational system by an elite group of individuals who strategically dominate the educational arena and attempt to perpetuate the ideology of supremacy of gender, race and socioeconomic status as it relates to the education of citizens in the country. For this reason, ODL environments are by no means immune to the problems arising from cultural differences. Fundamentally, these environments may even be more prone to cultural conflicts than traditional classrooms as ODL practitioners in these settings not only interact with students who have removed themselves from their native culture, but they also interact with students who physically and socially remain within the different culture, a culture that is foreign to them, and mostly unknown, to the ODL practitioners.

Central to this article is the assumption that students, in one hand, from diverse backgrounds bring to teaching and learning environments a wealth of cultural knowledge. ODL practitioners on the other hand, approach ODL teaching and learning from a personal cultural framework, but their cultural norms, values, expectations, and habits may look very different from those of their students. Scherff and Spector (2010) believe that ODL practitioners perceive students, all of whom are cultural agents, with inevitable prejudice and preconception. In the midst of this, basing ODL teaching and learning on one set of values, namely the dominant values, in culturally diverse settings usually results in what Antonio 
Gramsci (1971) calls "cultural hegemony" - a phenomenon that refers to the ways in which assumptions of a group/person achieve dominance over another and are viewed as common-sense understandings or interests that serve for all. However, several scholars have remarked on the issue of cultural hegemony in traditional classrooms and have proposed theories advocating incorporation of multiple cultures in school curricula. Such theories include, but are not limited to, "culturally relevant pedagogy" (Ladson-Billings, 1995a; Scherff \& Spector, 2010), "culturally responsive teaching" (Gay, 2000; Taylor \& Sobel, 2011), "culturally sensitive instruction" (Boyer, 1993), and "multicultural instruction" (Taylor \& Sobel, 2011). These are valuable contributions that provide useful frameworks for understanding and dealing with issues of culture in traditional multicultural classrooms.

Notwithstanding the abundance of literature available on the ODL, there are not many works that explore issues of cultural hegemony in an increasingly ethnic and culturally diverse student teaching and learning setting. As Brown (2000:126) purports, the emergence of multiculturalism raises major issues for the sense of national community, in that it challenges both the civic idea that the nation is a community of equal individual citizens and the ethno cultural (dominant society) idea that the nation is a community whose members ought to be culturally assimilating. Following Gramsci (1971), three important questions emerge. First, does cultural hegemony matter in Unisa's ODL? Second, what role can culturally relevant pedagogy (CRT) play in the Unisa's ODL environment? Third, are ODL practitioners sufficiently prepared for a culturally and linguistically diverse student population? If so, how do ODL practitioners and students navigate different cultures of learning in these environments? These are the kinds of questions that need specific attention if our aim is to improve ODL theory and practice. Drawing on Antonio Gramsci's work and culturally relevant pedagogy, this article: (1) sketches the genesis of cultural hegemony; (2) explores the philosophical background of culturally relevant pedagogy; (3) argues for culturally relevant pedagogy as a theory and practice of education; and (4) proposes a reengineering of ODL within culturally relevant pedagogy framework.

\section{Genesis of cultural hegemony}

In many respects, the convoluted and protracted discourses about "cultural hegemony" are mainly philosophical and political. First and foremost, the concept of cultural hegemony initially came from the concept of "hegemony". However, hegemony, as a social and multilayered construct, has a very rich history and is old as human being and has its traces in the ancient Greece (8th C. BC - AD 6th c.). Etymologically, the term hegemony is derived from the Greek word, egemonia, whose root is egemon, meaning "leader, ruler, often in the sense of a state other than his own" (Williams 1985). Since the 19th and early 20th centuries, hegemony has commonly been used to indicate political predominance, usually of one state over another. Italian communist, philosopher, journalist and socialist politician, Antonio Gramsci is correctly widely credited as having rejuvenated and revolutionised the theory of cultural hegemony. The term hegemony, as Gramsci (1971) notes, refers to the dominance of one group over other groups, with or without the threat of force. It is the form of ideological control to help explain the paradox that material inequality persists in societies that are governed by self-rule.

Much has been written about hegemony. In Gramsci's theory, hegemony is the term for the social consensus, which masks people's real interests. The hegemonic processes take place in the superstructure and are part of a political field (Giroux, 1997:45; Jørgensen \& Phillips 2002:32). In elaborating on this concept of hegemony, the basic premise of the theory of hegemony is that man is not ruled by force alone, but also by ideas. As Gramsci (1971) writes that the foundation of a ruling class is equivalent to the creation of a Weltanschauung. Marx has likewise also observed that the ruling ideas of each age have ever been the ideas of its ruling class (Bates 1975). Gramsci, however, finds this simple fact much more suggestive than Marx has, for whom it was but a corollary of economic theory. Bates (1975) asserts that the Italian scholar Norberto Bobbio has aptly observed that Gramsci's debt to Lenin for the concept of hegemony is less than Gramsci claims. For Bobbio, the term was used more by Stalin than by Lenin, who preferred the terms "leadership" and "management" (rukovoditel and rukovodstvo), and when he did use hegemony it was synonymous with leadership (Bates, 1975).

In a Gramscian sense, hegemony describes the power exercised by the ruling class over the population in order to maintain control of the means of production. Famously, Gramsci stated that hegemony is a form of control exercised primarily through a society's superstructure, as opposed to its base or social relations of production of a predominately economic character. The aim of hegemony, according to Gramsci (1971), is not only to create a collective will, but an entire new conception of the world or Weltanshaung. For him, hegemony has no unconscious foundation. It contrasts with dictatorship as a distinctive form of domination that combines force and consent without force ever disappearing, and in which force is itself the object of consent. Briefly, hegemony is consent protected by the armour of coercion. 
It is worth noting that through the power of consent, hegemony finds its way towards obtaining the spontaneous collaboration of the individuals, in order to uphold the political status quo in the long term. By hegemony, Gramsci (1971) meant the permeation throughout society of an entire system of values, attitudes, beliefs and morality that has the effect of supporting the status quo in power relations. Hegemony in this sense might be defined as an organising principle that is diffused by the process of socialisation into every area of daily life. To the extent that this prevailing consciousness is internalised by the population it becomes part of what is generally called "common sense" so that the philosophy, culture and morality of the ruling elite comes to appear as the natural order of things (Boggs, 1976:39).

It goes without saying that in its loosest sense, hegemony is not a static concept - it is very complex and fluid in nature. Like Gramsci, Williams (1985) believes that hegemony is dynamic - it does not just passively exist as a form of dominance. It has to be continually renewed, recreated, defended, and modified. It is also continually resisted, limited, altered, challenged by pressures not all its own. Furthermore, hegemony exceeds ideology in its refusal to equate consciousness with the articulate formal system which can be and ordinarily abstracted as ideology (Williams, 1985). Lastly, hegemony attempts to neutralise opposition hence, the decisive hegemonic function is to control or transform or even incorporate (alternatives and opposition).

To end this section, cultural hegemony, as a relative concept, does not refer anymore to western rationality and lifestyle conceived by the ruling classes (Hanafi, 2009). Rather, it refers to a more complex set of discursive strategies of combining principles from different systems of thought into one coherent ideology (Laclau \& Mouffe, 1985; Phillips, 1998). Hegemony, for Williams (1985), constitutes lived experience, a sense of reality for most people in the society, a sense of absolute because experienced reality beyond which it is very difficult for most members of the society to move, in most areas of their lives. Cultural hegemony has thus not produced cultural differences but instead cultural racism, xenophobia, and Islamophobia in the majority of western countries (Hanafi, 2009). Whether one imagines hegemony to be relatively open or relatively closed, the essence of the concept is not manipulation but legitimation. The ideas, values, and experiences of dominant groups are validated in public discourse; those of subordinate groups are not, though they may continue to thrive beyond the boundaries of received opinion (Lears, 1985).

\section{Philosophical background of culturally relevant pedagogy}

It is perhaps accurate and fitting to commence this section by asking the question: What is culturally responsive pedagogy (CRP)? CRP, also called culturally sensitive pedagogy, is not a new concept and has a rich history. Gay (2000:29) defines CRP as using the cultural knowledge, prior experiences and performance styles of diverse students to make learning more appropriate and effective for them; it teaches to and through the strengths of these students. Among others, CRP has had an immense influence through the works of Gloria Ladson-Billings, Geneva Gay, Elizabeth Moje, Kathleen Hinchman and Coffey Heather. These proponents' works perhaps offer important theoretical considerations in the development of culturally sensitive teaching approaches. At the heart of CRP is the assumption that culture is fundamental to learning - it provides the very grounds for human communication and interaction; and it is also a source of domination (Swartz, 1997:1). Culture refers to the system of shared beliefs, values, customs, behaviours and artifacts that members of a society use to interact with their world and one another - it drives values development and binds people together (Bourdieu 1973; Bourdieu \& Passeron, 1977). CRP is a pedagogy that empowers students by using cultural referents to impart knowledge; and it moves between two cultures but recognises each as legitimate. For Bourdieu (1973), cultural capital is a form of cultural transmission that individuals acquire from their given social structure. Cultural capital embodies the norms, social practices, ideologies, language and behaviour that are part of a given context (Bourdieu, 1973; Bourdieu \& Passeron, 1977).

Like other progressive CRP proponents, Gay (2000:29) describes CRP as having these attributes:

a) It acknowledges the legitimacy of the cultural heritages of different ethnic groups, both as legacies that affect students' dispositions, attitudes, and approaches to learning and as worthy content to be taught in the formal curriculum.

b) It builds bridges of meaningfulness between home and school experiences as well as between academic abstractions and lived sociocultural realities.

c) It uses a wide variety of instructional strategies that are connected to different learning styles.

d) It teaches students to know and praise their own and each others' cultural heritages.

e) It incorporates multicultural information, resource, and materials in all the subjects and skills routinely taught in schools. 
A wide range of studies have increasingly shown that CRP recognises, respects and uses students' identities and backgrounds as meaningful sources for creating optimal learning environments. Ladson-Billings (1992a; 1992b; 1994a;1994b; 2001) suggests that CRP acknowledges, responds to and celebrates fundamental cultures, as well as offering full, equitable access to education for students from all cultures; consequently recognising the importance of including students' cultural references in all aspects of learning. Hence, Bourdieu (1973) argues that education systems often institute pedagogic action, which requires a familiarisation with the dominant culture and all its beliefs, behaviours and ideals.

In its most general sense, the purpose of CRP is the maximisation of learning for racially and ethnically diverse students. It is important to recognise, however, that all students, regardless of race or ethnicity, bring their culturally influenced cognition, behaviour and dispositions with them to school. Thus the efficacy of CRP is not limited to students of colour even though the term is most often used to describe effective teaching of racially and ethnically diverse students (Villegas, 1991; Villegas \& Lucas, 2002). CRP builds on the premise that "how people are expected to go about learning may differ across cultures". To maximise learning opportunities, teachers must gain knowledge of the cultures represented in their classrooms, then translate this knowledge into instructional practice (Villegas, 1991; Villegas \& Lucas, 2002; Pitsoe \& Dichaba, 2013). However, student achievement is not the only purpose of a CRP. Teachers must also assist students to change society not simply to exist or survive in it.

For us, CRP facilitates and supports the achievement of all students. Richards et al. (2007) contend that in a culturally responsive classroom, effective teaching and learning occur in a culturally supported, learner-centred context, whereby the strengths students bring to school are identified, nurtured, and used to promote student achievement. CRP comprises three dimensions: (a) institutional, (b) personal, and (c) instructional. The institutional dimension reflects the administration and its policies and values. The personal dimension refers to the cognitive and emotional processes that teachers must engage in to become culturally responsive. The instructional dimension includes material, strategies and activities that form the basis of instruction. All three dimensions significantly interact in the teaching and learning process and are critical to understanding the effectiveness of culturally responsive pedagogy. While all three dimensions are important, because of space limitations only a few points will be made about the institutional dimension. This brief focuses on the two most relevant for teachers' work: the personal and instructional dimensions (Richards et al., 2007).

\section{Culturally relevant pedagogy as theory and practice of education}

The concept culture is very complex and broadly perceived - it is central to CRP. For example, the poststructuralist trinity (Lacan, Derrida and Foucault) note that culture as a category of social life has itself been conceptualised in a number of different ways. Among others, they see culture as: (1) creativity or agency, (2) a system of symbols and meanings, and (3) practice. Culture is neither a particular kind of practice nor practice that takes place in a particular social location. It is rather the semiotic dimension of human social practice in general (Sewell, 2005:48). As observed by most celebrated and influential scholars (Ladson-Billings, 1992a; 1992b; 1994a; 1994b; 2001; McLaren, 1995; Gay, 2010; Taylor \& Sobel, 2011; Scherff \& Spector, 2010; Swartz, 1997; Giroux, 1997; Nieto \& Bode, 2010; 2011; Johnson \& McElroy, 2012; Pitsoe \& Dichaba, 2013), culture is central to learning (including curriculum, instruction, interactions, and assessment). It plays a role not only in communicating and receiving information, but also in shaping the thinking processes of groups and individuals (Scherff \& Spector, 2010; Taylor \& Sobel, 2011). A pedagogy that acknowledges, responds to, and celebrates fundamental cultures offers full, equitable access to education for students from all cultures (Ladson-Billings, 1994a; 1994b; 2001).

Numerous conceptualisations of CRP exist. For example, the term culturally relevant pedagogy is used interchangeably with several terms, such as culturally responsive, culturally appropriate, culturally congruent and culturally compatible, to describe effective pedagogy in culturally diverse classrooms. It is a pedagogy that empowers students intellectually, socially, emotionally, and politically by using cultural referents to impart knowledge, skills and attitudes (Ladson-Billings, 1992a; 1992b; 1994a; 1994b; 2001; Scherff \& Spector, 2010; Taylor \& Sobel, 2011). For Gay (2000; 2010), CRT uses cultural knowledge, prior experiences, and performance styles of diverse students to make learning more appropriate and effective for them; it teaches to and through the strengths of these students.

It is important to emphasise that a significant number of scholars (Ladson-Billings, 1994a; Ladson-Billings, 1994b; Asante, 1991/1992; Au, 1993; Erickson, 1987; Gordon, 1993; Smith \& Ayers, 2006; Lipman, 1995; Gay 2000; Pewewardy, 1994; Philips, 1983; Scherff \& Spector, 2010) perceive CRT as liberating, transformative, comprehensive, validating, empowering, emancipatory and transformative. In addition, they perceive it as something that guides students in understanding that no single version of "truth" is total and permanent. It does not solely prescribe to mainstream ways 
of knowing. CRT infuses family customs - as well as community culture and expectations - throughout the teaching and learning environment (Ladson-Billings, 1994a; Ladson-Billings, 1994b; Gay, 2000). In addition, by providing instruction in a context meaningful to students and in a way that values their culture, knowledge, and experiences, CRT fosters student motivation and engagement. Central to CRT, as Gay (2000:37) notes, is making authentic knowledge about ethnic groups accessible to students. Furthermore the validation, information, and the pride it generates are both psychologically and intellectually liberating.

Gay (2000:31-32) expressly notes that while improving academic achievement and developing a sense of community, camaraderie, and shared responsibility is a goal of CRP, education of this sort can be multidimensional for teachers and learners:

Culturally responsive teaching requires tapping into a wide range of cultural knowledge, experiences, contributions, and perspectives. Emotions, beliefs, values, ethos, opinions, and feelings are scrutinized along with factual information to make curriculum and instruction more reflective of and responsive to ethnic diversity. However, every conceivable aspect of an ethnic group's culture is not replicated in the classroom. Nor are the cultures included in the curriculum used only with students from that ethnic group. Cultural responsive pedagogy focuses on those elements of cultural socialization that most directly affect learning.

For Ladson-Billings (1992:382), culturally responsive teachers develop intellectual, social, emotional, and political learning by "using cultural referents to impart knowledge, skills, and attitudes". Among others, cooperation, community and connectedness are central attributes of culturally responsive teaching. Gay (2000:38) asserts that students are expected to work together and get accolades for one another's success and held accountable for one another's failures. The goal is for all students to be winners, rather than some who win and others who lose, and for some students to assume responsibility for helping one another achieve to the best of their ability (Gay, 2000:38).

To conclude, CRT is "using the cultural knowledge, prior experiences, and performance styles of diverse students to make learning more appropriate and effective for them. It lifts the veil of presumed absolute authority from conceptions of scholarly truth typically taught in schools; and helps students realise that no single version of truth is total and permanent (Gay 2010). It does not make itself the mainstream way of knowing or learning. To accomplish this, teachers make real knowledge about different cultures and ethnic groups accessible to students. The validation, information, and pride it generates are both psychologically and intellectually liberating (Gay, 2010).

\section{Reengineering ODL within culturally relevant pedagogy framework}

Today, culturally diverse settings in ODL call for a reengineering in terms of teaching (instruction) and learning approaches, curriculum design, interactions, and assessment to the ones that are more responsive to the life experiences of the other ethnic groups of students. Notwithstanding the high throughput rate, Unisa's ODL classroom settings fit the profile of McLaren (1995) and Giroux (1997), as they are seen as sites for locating students in subject positions that do not contest the discursive assumptions, dispositions, and dimensions of the dominant culture - student gestures become reified into corporeal manifestations of hegemony. Without succumbing to cultural hegemony, it is important to acknowledge that employing CRP in Unisa's ODL has the prospects of providing practitioners with theoretical basis and tools in good teaching and learning (including curriculum, instruction, interactions, and assessment). Most importantly, ODL practitioners can use students' cultural frames of reference and background knowledge to guide their instruction and implementation of curriculum in ways to maximise relevance for all students. Good teaching, as Taylor and Sobel (2011:204) write, is responsive instruction in which teachers provide instructional strategies and curriculum consistent with students' life experiences, prior knowledge, and frames of reference and filtered through students' cultural lens. Thus, learning is not simply a cognitive process but also a cultural process - a social construction of reality.

While we acknowledge the limitations of CRP, cultural appropriateness, congruence, or compatibility plays a critical role in ODL teaching and learning setting. We hold that educational practices must match with the students' culture in ways which ensure the generation of academically important behaviours. Hence, there is a dare need to develop a knowledge base, designing culturally relevant curricula, demonstrating cultural caring and building a learning community, building effective cross-cultural communications, and delivering culturally responsive instruction in higher education institutions. Sadly, evidence shows that most of the practitioners are inadequately prepared to teach students from culturally diverse backgrounds. However, culture deeply influences the way students learn. For Gay (2012), culture encompasses many things, some of which are more important for teachers to know than others because they have direct 
implications for teaching and learning. Among these are ethnic groups' cultural values, traditions, communication, learning styles, contributions, and relational patterns (Gay, 2010).

Following Gay (2010), McLaren (1995) and Giroux (1997), we hold that university teachers should enlarge the curriculum reflect the richness and diversity of the students they actuality teach.

Given that Unisa is one of the largest higher education institutions in Africa (serving students from diverse cultural backgrounds) there are enormous striking challenges facing its ODL theory and practice. Within diverse cultural ODL setting, practitioners' attitudes must reflect an appreciation of the cultural, linguistic, and social characteristics of each of their students. For this reason, acquiring a knowledge base about ethnic and cultural diversity for ODL practitioners offers different opportunities for teaching cultural diversity. As part of reversing the underachievement of diverse cultural students, we argue that significant changes are needed in how these students are taught. Central to this article is the assumption that CRP aims to expose and eradicate the hegemony that permeates almost every aspect of society, including schools and universities. Hence, culturally CRP provides marginalised students with the tools to aid in effecting change. The voices of the culturally marginalised students are often absent from the "mainstream" discourse, and the issues that are most important to these students are frequently ignored. Culturally relevant pedagogy, as Howard (2001) notes, recognises the cogent role that cultural socialisation plays in how students receive, analyse, and interpret information and structure instruction accordingly.

In a recent series of exceptionably able writings, a significant number of scholars (Sheets 1995; Gay, 2010; Howard, 2001; Ladson-Billings, 1994; Shade, Kelly, \& Oberg, 1997; Pitsoe \& Dichaba, 2013) consider CRP as an effective means of meeting the academic and social needs of culturally diverse students. Gay (2010) asserts that culturally relevant pedagogy uses "the cultural knowledge, prior experiences, frames of reference, and performance styles of ethnically diverse students to make learning more relevant to and effective [for students]". It teaches to and through strengths of these students. It is culturally validating and affirming (Gay, 2010). Among others, it needs to underpin its ODL (teaching and learning) by culturally relevant pedagogy frames of reference. As Gay (2010) writes, research, theory and practice attest to their potential effectiveness. Against this backdrop, the following question then comes into mind: Is Unisa's ODL (teaching and learning) matching the students' generational culture and/or is it compatible with practices which speak to culturally diverse students?

Cordington and Grant-Marshall (2011:135) note that education has become a massive and hotly competitive industry, and educational institutions have to change rapidly to keep up with new trends. In addition, in each generation a specific style of teaching and learning has predominated. Given that Unisa's students are spread across the different generational categories, it is important to recognise these styles, as they have influenced not only how we learn but also how we teach. It goes without saying that Unisa's ODL has historically been rooted in a standard set of operating procedures which has defined teaching and learning as separate, absolute entities where the teacher dictates a set of behaviours for the student to follow.

Unfortunately, there is a missing link between theory and practice - Unisa's ODL seem deny cultural diversity, and assumes that educational experiences are the same for all students in terms of generational divide. Current practice appears not to be promoting equity and inclusion among culturally diverse students in the instructional design. Given the current diverse student population, Unisa's ODL must be redefined to meet the needs and demands of a diverse generational culture. For this reason, we propose that Unisa's ODL needs to develop strategies to assist students who come from an array of diverse backgrounds. Differences in our ODL students are apparent in regard to generation, race, social class, religion, languages, dress, cultural practices, and activity choices. Hence, coupled with the changing cultural/racial demographics in the general student population, there is a need to "bridge the gap" between race, social class, religion, languages, dress, cultural practices, and ODL.

Smith and Ayers (2006) assert that in light of the conceptual relationships between culture and learning, it becomes crucial for teachers to reflect critically upon educational practices that accommodate the diverse needs of learners from different cultural backgrounds. To promote equitable environments for learning, it is imperative that culturally responsive methods of instruction are used to assist us in delivering content that will aid in promoting lifelong wellness for everyone we influence. In this article we strive to respond to the following pertinent question: "How can Unisa's ODL provide a teaching and learning environment which puts all students in the best possible position to excel?" We maintain that CRP has the prospects of this question. Among others, CRP facilitates and supports the achievement of all students. In a culturally responsive classroom, effective teaching and learning occur in a culturally-supported, learner-centred context, whereby the strengths students bring to school are identified, nurtured, and used to promote student achievement (Richards, Brown \& Forde, 2007:64). Culturally responsive pedagogy involves three dimensions 
which aid in creating successful learning environments for diverse learners: (a) institutional, (b) personal, and (c) instructional.

In conclusion, we perceive CRT in ODL settings as all about using culture and experiences of different ethnic groups as a way to teach more effectively. A culturally relevant teaching must provide a way for students to maintain their cultural identity, while succeeding academically. We recognise the challenges of Unisa's ODL, however we propose reimagining ODL practice through the lens of a methodological framework for promoting equity and cultural sensitivity in open distance learning. Among others, this lens accommodate: (a) cultural maintenance, (b) ownership of learning, (c) communities of inquiry, and (d) provisions of multiple perspectives.

For Unisa's ODL to be responsive to the cultural uniqueness of its diverse students, it must emerge in the planning, design, implementation, and assessment of learning experiences, particularly those offered at a distance through instructional technologies. In addition, it should recognise the inconsistency with which students of various world views may interpret the world around them. The design of ODL experiences should draw from many educational philosophies, learning theories, and pedagogical methods compatible and consistent with CRP. We hold that educational programmes must be reengineered and aligned with students' needs, interests, values, student perceptions, communication styles, and desired learning outcomes that apply within a particular cultural context.

\section{Conclusion}

In summary, effective teaching and learning in an ODL setting has to be fluid and adaptive to diverse cultures. At philosophical level, best practices of ODL are consistent with multicultural education. In the case of Unisa's ODL, practitioners often do not know the ethnicity or background of their students. With this in mind, it is important for Unisa to make every effort possible to really get to know its students - Unisa cannot single out certain students based on their culture or background. For this reason, it is important for practitioners to try and actively learn about the students that they are teaching. We maintain that to be culturally diverse is to shift our teaching styles to be more responsive to the life experiences of the other ethnic groups instead of the other ethnicities conforming to our experiences. Effective teaching and learning cannot take place without learning the backgrounds of each student. With today's ODL environment becoming so ethnically diverse, it is important to gain an understanding of the student's background and current situation. ODL environments are by no means immune to the problems arising from cultural and generational differences. Fundamentally, these environments may even be more prone to cultural conflicts than traditional classrooms as practitioners in these settings not only interact with students who have removed themselves from their native cultures but they also interact with students who remain "physically and socially within the different culture, a culture that is foreign to, and mostly unknown, to the teacher".

\section{References}

Asante, MK. (1991/19920. Afrocentric curriculum. Educational Leadership, 49(4): 28-31.

Au, KH. (1993). Literacy Instruction in Multicultural Settings. New York: Harcourt Brace.

Bates TR (1975). Gramsci and the Theory of Hegemony. Journal of the History of Ideas, 36(2): 351-366.

Boggs, C. (1976) Gramsci's Marxism. London: Pluto Press.

Bourdieu, P. (1973). Cultural reproduction and social reproduction, in Knowledge, education and cultural change, edited by R Brown. London: Tavistock: pp. 71-112.

Bourdieu, P. \& Passeron, J.C. (1977). Reproduction in education, society and culture. London: Sage.

Boyer, J.B. (1993) Culturally Sensitive Instruction: An essential component of education for diversity. Catalist for Change, 22(2), 5-8.

Brown, D. (2000) Contemporary Nationalism: Civic, Ethnocultural and Multicultural Politics. London: Routledge

Cordington, G. \& Grant-Marshall, S. (2011). Mind the gap. Johannesburg: Penguin Books.

Erickson, F. 1987. Transformation and school success: the politics and culture of educational achievement. Anthropology and Education Quarterly, 18(4): 335-383.

Gay, G. (2000). Culturally Responsive Teaching: Theory, Research \& Practice. New York: Teachers College Press.

Gay, G. (2010). Culturally Responsive Teaching: Theory, Research, and Practice, Second Edition. New York: Teachers College Press.

Giroux, H.A. (1997). Pedagogy and the Politics of Hope: Theory, Culture, and Schooling. Oxford: Westview Press.

Gordon, B.M. (1993). African American cultural knowledge and liberatory education; dilemmas, problems, and potentials in a postmodern American society. Urban Education, 27(4): 448-470.

Gramsci, A. (1971). Selections from the prison notebooks. London: Lawrence and Wishart.

Hanafi, S. (2009). Cultural Diff erence or Cultural Hegemony? Contextualizing the Danish Cartoon Controversy within Migration Spaces. Middle East Journal of Culture and Communication, 2: 136-152. 
Howard, T.C. (2001). Powerful pedagogy for African American students: Conceptions of culturally relevant pedagogy. Urban Education, 36(2): 179-202.

Johnson, B. \& McElroy, T.M. (2012). The Changing Role of the Teacher in the 21st Century.

Teachers Net Gazzette, 9(10). From http://teachers.net/gazette/wordpress/dr-brad-johnson-tammy-maxson-mcelroy/changing-role-ofthe-teacher/ Accessed on 15 October 2012.

Jørgensen, M. \& Phillips, L. (2002). Discourse Analysis as Theory and Method London: SAGE Publications

Ladson-Billings, B. (1992a). Reading between the lines and beyond the pages: A culturally relevant approach to literacy teaching. Theory Into Practice, 31(4): 312-320.

Ladson-Billings, G. (1992b). Liberatory consequences of literacy: A case of culturally relevant instruction for African American students. Journal of Negro Education, 61(3): 378-391.

Ladson-Billings, G. (1994a). The Dreamkeepers: successful teaching for African-American students. San Francisco: Jossey-Bass.

Ladson-Billings, G. (1994b). The Dreamkeepers. San Francisco: Jossey-Bass.

Ladson-Billings, G. (1995a). But that's just good teaching! The case for culturally relevant pedagogy. Theory Into Practice, 34(3): 159165.

Ladson-Billings, G. (1995b). Multicultural teacher education: Research, practice, and policy. In J.A. Banks \& C.A.M. Banks (Eds.) Handbook of Research on Multicultural Education. New York: Macmillan:747-759.

Ladson-Billings, G. (2001). Crossing over to Canaan: The journey of new teachers in diverse classrooms. San Francisco: Jossey-Bass.

Laclau, E. and Mouffe, C. (1985) Hegemony and Socialist Strategy. Towards a Radical Democratic Politics. London: Verso.

Lears, T.J.J (1985). The Concept of Cultural Hegemony: Problems and Possibilities. The American Historical Review, 90(3): 567-593

Lipman, P. (1995). "Bringing out the best in them": The contribution of culturally relevant teachers to educational reform. Theory Into Practice, 34(3): 202-208.

Moll, L. (1992). Literacy research into communities and classrooms: A sociocultural approach. In R. Beach, J. Green, \& T. Shanahan (eds). Multidisciplinary perspectives in literacy research. Urbana, IL: National Council of Teachers of English. pp. 47-73.

McLaren, P. (1995). Critical Pedagogy and Predatory Culture: Oppositional politics in a postmodern era. London: Routledge.

Nieto, S., \& Bode, P. (2011). Affirming diversity: The sociopolitical context of multicultural education.Boston, MA: Allyn \& Bacon.

Nieto, S. (2010). The light in their eyes: Creating multicultural learning communities. New York, NY: Teachers College Press.

Pewewardy, C.D. (1994). Culturally responsive pedagogy in action: An American Indian magnet school. In ER. Hollins, JE. King, \& WC. Hayman (eds), Teaching Diverse Populations: Formulating a Knowledge Base. Albany: State University of New York Press:7792.

Phillips, L. (1998). 'Hegemony and political discourse: the lasting impact of Thatcherism', Sociology, 32(4): 847-67.

Philips, S.U. (1983). The Invisible Culture: Communication in Classroom and Community on the Warm Springs Indian Reservation. Prospect Heights, IL: Waveland.

Pitsoe, V.J. \& Dichaba, M.M. (2013), "Reimagining UNISA's open distance learning through the lens of culturally relevant pedagogy", International Journal of Development and Sustainability, Vol. 2 No. 1 (In Press).

Richards, H., Brown, A. \& Forde, T. (2007). Addressing diversity in schools: culturally responsive pedagogy. Teaching Exceptional Children, 23(3): 64-68.

Santamaría, L.J. (2009). Culturally responsive differentiated instruction: Narrowing gaps between best pedagogical practices benefiting all learners. Teachers College Record, Columbia University, 111(1): 214-247.

Scherff, L. \& Spector, K. (2010). Culturally Relevant Pedagogy: Clashes and Confrontations. New York: Rowman \& Litlefield Education.

Shade, B.J., Kelly, C., \& Oberg, M. (1997). Creating culturally responsive classrooms. Washington, DC: American Psychological Association.

Sheets, R.S. (1995). From remedial to gifted: Effects of culturally centered pedagogy. Theory Into Practice, 34:3, 186-193.

Sewell, W.H. (2005). The Concept(s) of Culture. In Spiegel, GM (ed). Practicing History: New Directions in Historical Writing after the Linguistic Turn. New York: Routledge.

Smith, D.R., \& Ayers, DF. (2006). Culturally responsive pedagogy and online learning: implications for the globalized community college. Community College Journal of Research and Practice, 30: 401-415.

Swartz, D. (1997). Culture and Power: The Sociology of Pierre Bourdieu. London: The University of Chicago Press.

Taylor, S.V. \& Sobel, D.M. (2011). Culturally Responsive Pedagogy: Teaching like our students' lives matter. London: Emerald Group Publishing Limited.

Villegas, AM. 1991. Culturally responsive pedagogy for the 1990's and beyond. (Trends and Issues Paper No. 6). Washington, DC: ERIC Clearinghouse on Teacher Education. (ERIC Document Reproduction Service No. ED339698).

Villegas, A. M. \& Lucas, T. (2002). Educating culturally responsive teachers: A coherent approach. Albany, NY: State University of New York Press.

Williams, R. (1985). A Vocabulary of Culture and Society. New York: Oxford 